\title{
Mortierella verticillata Linnem. (Mortierellomycota, Mortierellales) isolated from mountainous environments: a first report from South America
}

\author{
Camila Melo Gonçalves, Rafael José Vilela de Oliveira, Rejane Maria Ferreira da Silva, Carlos \\ Alberto Fragoso de Souza, Diogo Xavier Lima, Gladstone Alves da Silva
}

Graduate Program in Biology of Fungi, Department of Mycology, Federal University of Pernambuco, Av. Professor Nelson Chaves, s/n, 50670-420, Recife, PE, Brazil.

Corresponding author: Rafael José Vilela de Oliveira; rafaelvilela87@gmail.com

\begin{abstract}
During a study on filamentous fungi in the soil of mountainous environments in the state of Minas Gerais, Brazil, one specimen of Mortierella verticillata Linnem. was isolated. Fungal identity was confirmed by morphology and ITS rDNA sequence analysis. This study reports the first occurrence of M. verticillata in South America. This species is distinguished by its monopodial sporangiophores growing on aerial hyphae of verticillate branches, and single-spored sporangia finely ornamented with a diffluent wall. In this manuscript, the specimen is described and illustrated, and the distribution of this species is discussed.
\end{abstract}

\section{Keywords}

ITS rDNA, Mortierellomycotina, Southeastern Brazil, taxonomy.

\section{Introduction}

Mortierella Coem. comprises a diverse group of saprobe species that inhabit soil (Wagner et al. 2013). This genus currently belongs to the phylum Mortierellomycota Tedersoo, subphylum Mortierellomycotina Kerst. Hoffmann, Voigt \& P.M. Kirk (Tedersoo et al. 2018). Mortierella species are characterized by white cottony colonies with a rosette aspect, and a garlic odor is often present (Benny 2009; Wagner et al. 2013). The main characteristic of representatives from this genus is the production of sporangiophores with a swollen base, and lack of columellae (Gams 1977; Benny 2009; Wagner et al. 2013).

Species of this genus were classified by Gams (1977), who grouped them into nine sections based on morphology: Actinomortierella, Alpina, Haplosporangium, Hygrophila, Mortierella, Schmuckeri, Simplex, Spinosa, and Stylospora. The branching patterns of sporangiophores is the main characteristic to differentiate Mortierella sections. The Stylospora section comprises species that exhibit branches arising from the lower part of the 
sporangiophore. This section consists of six species: $M$. horticola Linnem., M. humilis Linnem. ex W. Gams, $M$. lignicola (G.W. Martin) W. Gams \& R. Moreau, M. stylospora Dixon-Stew., M. verticillata Linnem., and $M$. zonata Linnem. ex W. Gams.

The species Mortierella verticillata is morphologically characterized by the production of sporangiophores basitonously branched, tapering gradually at the top. Additionally, the single-spored sporangia are finely ornamented (Gams 1977). It has been mainly isolated from European countries such as Austria, England, Estonia, France, Germany, Poland, the Netherlands, Sweden and Ukraine, but was also reported in North America (Canada, Mexico, and USA, including Alaska) and Asia (China) (Linnemann 1941, 1958; Wagner et al. 2013).

In Brazil, ten species of Mortierella have been recorded: M. alpina Peyronel, M. ambigua B.S. Mehrotra, M. elongata Linnem., M. gamsii Milko, M. longicollis Dixon-Stew., M. microspora E. Wolf, M. oligospora Björl., M. parvispora Linnem., M. polycephala Coem., and M. subtilissima Oudem (Flora do Brasil 2020). During a study about the occurrence of filamentous fungi of soil in Brazil, one strain of $M$. verticillata was isolated.

The aim of the present study was to report and illustrate the species identified as Mortierella verticillata isolated from soil samples of the Caparaó mountain (Serra do Caparaó), Minas Gerais, Brazil.

\section{Methods}

Soil samples were collected from Serra do Caparaó, in Minas Gerais, at $1950 \mathrm{~m}$ altitude (Fig. 1). The mean annual temperature in the study area is about $19-22{ }^{\circ} \mathrm{C}$, and the mean annual precipitation is approximately 1,000 $\mathrm{mm}$. The dominant vegetation is montane forest (Pereira et al. 2012), and the area has a silty soil, with $\mathrm{pH}\left(\mathrm{H}_{2} \mathrm{O}\right)$ 5.21 , organic carbon $9.8 \%$, and available $\mathrm{P} 10.67 \mathrm{mg} / \mathrm{dm}^{3}$.

To isolate the fungi, the soil was subjected to a successive dilution technique (Clark 1965, modified), where $25 \mathrm{~g}$ of soil was suspended in $225 \mathrm{~mL}$ of sterile distilled water (1:10 dilution). Thereafter, $10 \mathrm{~mL}$ of this suspension was added to $990 \mathrm{~mL}$ sterile distilled water (1:1000 dilution), then $1 \mathrm{~mL}$ of this dilution was seeded in Sabouraud agar with chloramphenicol $(100 \mathrm{mg} / \mathrm{L})$ in petri dishes. Pure cultures of the isolates were grown on potato carrot agar (PCA) (containing $10 \mathrm{~g} / \mathrm{L}$ of potato and carrot plus $1.5 \%$ agar) and incubated at $20^{\circ} \mathrm{C}$ for 15 days.

Specimens were identified by observing macroscopic (colony color, appearance, and diameter) and microscopic characteristics, as described by Chien et al. (1974) and Gams (1977). The colors of the colonies were designated according to Maerz and Paul (1950). The fungal biomass was obtained for genomic DNA extraction as described by Oliveira et al. (2016). The primer pairs ITS1/ITS4 (White et al. 1990) were used to amplify the ITS region rDNA. The polymerase chain reaction was conducted as described by Oliveira et al. (2014). The

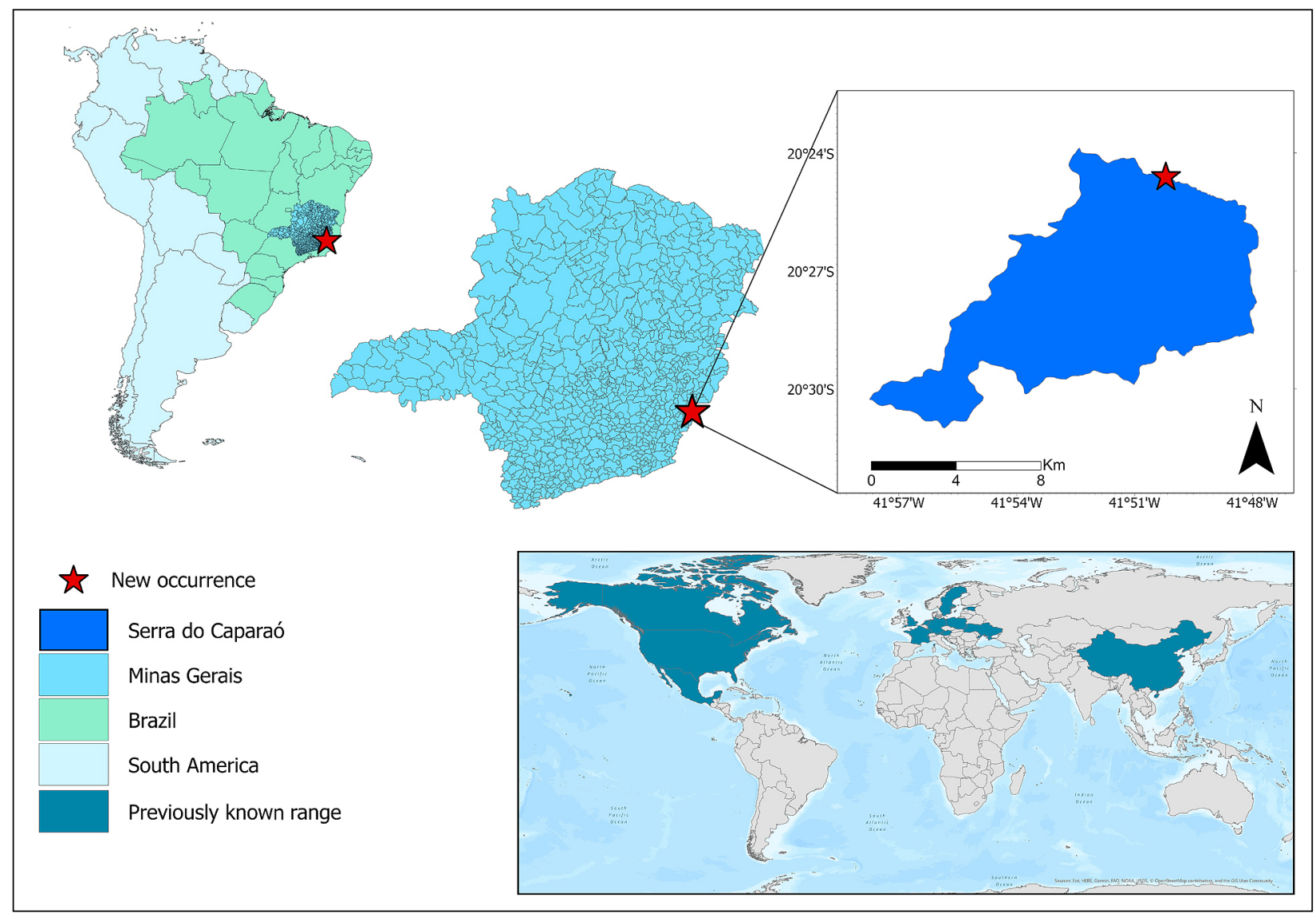

Figure 1. The location in South America where Mortierella verticillata URM 8180 was isolated and the previously range distribution. 
newly obtained sequence was deposited in GenBank (MN509002). Lyophilized culture of M. verticillata is deposited in the culture collections of Micoteca URM Profa. Maria Auxiliadora Cavalcanti, Federal University of Pernambuco, Recife, Brazil (www.ufpe.br/micoteca, WCDM 604).

Phylogenetic reconstructions were obtained by analyzing sequence data of the ITS rDNA. The sequence obtained was aligned with some other related fungal sequences from GenBank using MEGA, version 5.05 (Tamura et al. 2007). Prior to phylogenetic analysis, the optimal model of nucleotide substitution was estimated using Topali 2.5 (Milne et al. 2004). Bayesian inference analysis (two runs over $4 \times 10^{6}$ generations with a burnin of 2500) was performed with MrBayes 3.1.2 (Ronquist and Huelsenbeck 2003), launched from Topali 2.5.

\section{Results}

Mortierella verticillata Linnem., 1941; MucorineenGattung Mortierella Coemans 23: 22. Figures 2A-D

Material examined. BRAZIL 1 specimen; Minas Gerais, Serra do Caparaó; 20²4'35"S, 04150'12"W; Nov. 2018; isolated by Camila Melo Gonçalves; URM 8180; DNA barcode voucher MN509002.

Identification. After seven days at $20^{\circ} \mathrm{C}$ on PCA, white colonies with aspect rosette (MP 19D1), reverse cream (MP 11J6), reaching $9 \mathrm{~cm}$ in diameter and up to $1 \mathrm{~cm}$ in height. Aerial hyphae abundant. Sporangiophores erect, $50-150 \mu \mathrm{m}$ long and $3.5 \mu \mathrm{m}$ in diameter. Near the base of the sporangiophores up to six verticillate branches, vertically arising from aerial hyphae. Sporangia one-spored,
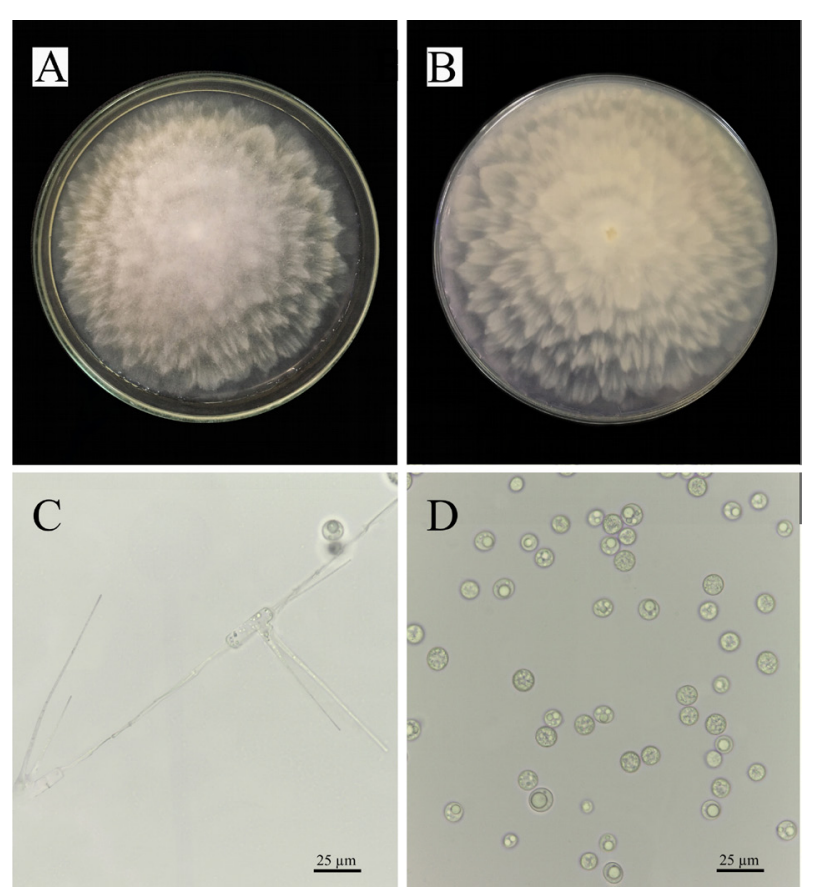

Figure 2. Mortierella verticillata. A. Top view of the colony. B. Bottom view of the colony. C. Verticillate sporangiophores arising on aerial hyphae. D. Unispored sporangia. globose, 9-15 $\mu \mathrm{m}$ in diameter, finely ornamented, with a diffluent wall, grayish to brown, with some granular contents. Columella and collar absent. Chlamydospores not observed. Zygosporangia not observed.

In the phylogenetic tree, the sequence of $M$. verticillata (URM 8180) forms a clade together with other $M$. verticillata and M. humilis sequences (Fig. 3).

\section{Discussion}

The morphological characteristics of the specimen Mortierella verticillata URM 8180 are similar to those described by Linnemann (1941). According to Gams (1977), M. verticillata can be easily distinguished from other species of the Stylospora section. Sporangiophores of $M$. lignicola strongly taper from the middle part to the tip, whereas that of $M$. verticillata taper gradually to the tip; $M$. stylospora has sporangia with reticulate walls while $M$. zonata sporangia are smooth walled, but both differ from the finely ornamented sporangia of $M$. verticillata.

Mortierella humilis, however, exhibit morphological characteristics similar to $M$. verticillata that often cause difficulties in distinguishing them (Chien et al. 1974). Thus, the traditional taxonomy of $M$. verticillata and $M$.

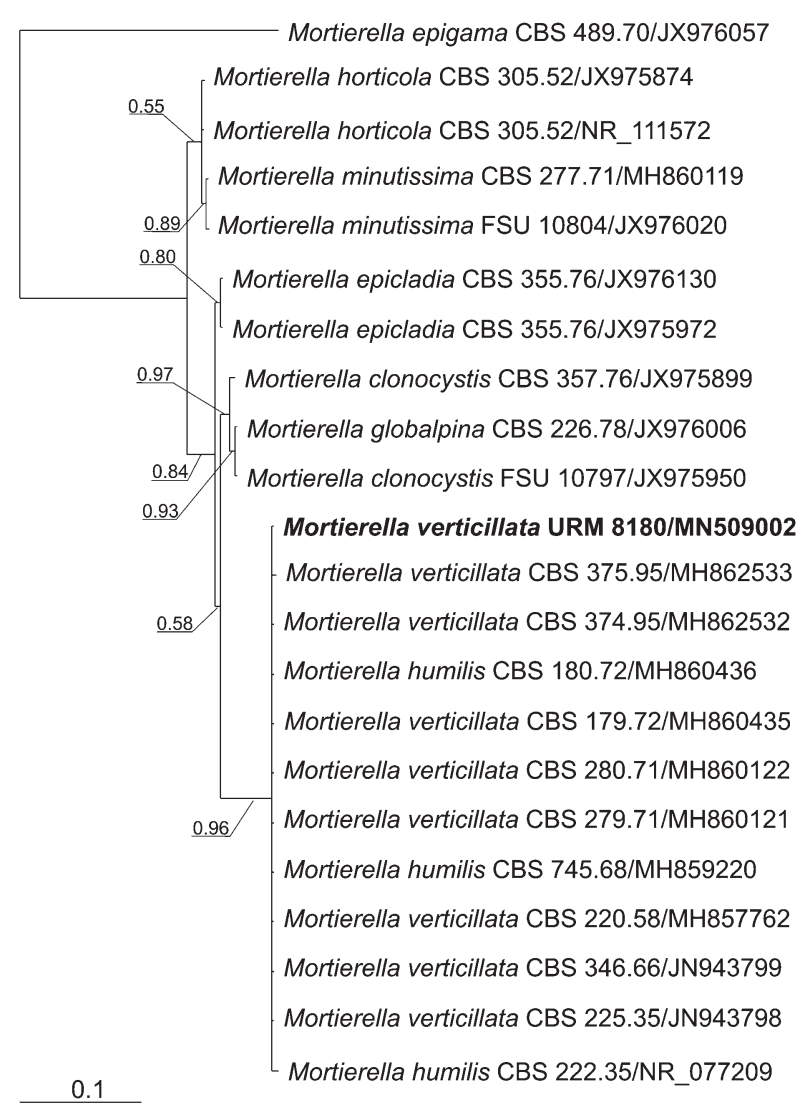

Figure 3. Phylogenetic tree of Mortierella verticillata and related species, constructed using ITS rDNA sequences. Mortierella epigama W. Gams \& Domsch was used as outgroup. Sequences are labeled with the corresponding GenBank accession numbers. Support values were obtained from Bayesian analysis. The sequence obtained in this study is annotated in bold font. 
humilis has been largely based on minor variations in asexual morphological characteristics; such as the sporangia, with an outermost layer that is firmly attached in $M$. humilis and absent in M. verticillata (Chien et al. 1974; Gams 1977).

In BLASTn analysis, the ITS rDNA sequence MN509002 had $99.67 \%$ identity with $M$. verticillata MH860122 (CBS 280.71) and 99.34\% with M. humilis NR_077209 (CBS 222.35). Our phylogenetic tree shows that the sequence from URM 8180 forms a clade together with sequences from $M$. verticillata and $M$. humilis. According to Wagner et al. (2013), differentiation between $M$. verticillata and $M$. humilis based on ITS sequences is not possible, and both species are morphologically similar. Thus, the authors suggest that $M$. verticillata and M. humilis should be synonymized. Neither species has been reported in South America.

Here, we report the first occurrence of $M$. verticillata in South America (Fig. 1), increasing the knowledge of the distribution of this species worldwide.

\section{Acknowledgements}

This manuscript was financed by the National Council for Scientific and Technological Development (CNPq Universal Application; process \#458391/2014-0).

\section{Authors' Contributions}

CMG collected the material; RJVO and RMFS performed the specified methodology; CMG and GAS wrote the text; and CAFS and DXL identified the species.

\section{References}

Benny GL (2009) Zygomycetes. http://www.zygomycetes.org/index. php?id=84. Accessed on: 2019-6-5.

Clark FE (1965) Agar-plate method for total microbial count. In: Black CA, Evans DD, White JL, Esminger LE, Clark FE, Dinaver RC (Eds) Methods of soil analysis, part 2. Chemical and microbiological properties. American Society of Agronomy, Madison, $1460-1466$.

Chien CY, Kuhlman EG, Gams W (1974) Zygospores in two Mortierella species with "stylospores”. Mycologia 66 (1): 114-121. https:// doi.org/10.1080/00275514.1974.12019580
Flora do Brasil (2020). Jardim Botânico do Rio de Janeiro. http:// floradobrasil.jbrj.gov.br. Accessed on: 2020-5-24.

Gams W (1977) A key to the species of Mortierella. Persoonia 9: 381391.

Linnemann G (1941) Die Mucorineen-Gattung Mortierella Coemans. Pflanzenforschung, Heft 23: 1-64.

Linnemann G (1958) Untersuchungen zur Verbreitung und Systematik der Mortierellen. Archives of Microbiology 30 (3): 256-267.

Maerz AJ, Paul MR (1950) A dictionary of color. 2nd ed. McGrawHill Book Company, New York, 208 pp.

Milne I, Wright F, Rowe G, Marshall DF, Husmeier D, McGuire G (2004) TOPALi: software for automatic identification of recombinant sequences within DNA multiple alignments. Bioinformatics 20 (11): 1806-1807.

Oliveira RJV, Lima TEF, Cunha IB, Coimbra VRM, Silva GA, Bezerra JL, Cavalcanti MAQ (2014) Corniculariella brasiliensis, a new species of coelomycetes in the rhizosphere of Caesalpinia echinata (Fabaceae, Caesalpinioideae) in Brazil. Phytotaxa 178 (3): 197-204. https://doi.org/10.11646/phytotaxa.178.3.5

Oliveira RJV, Bezerra JL, Lima TEF, Silva GA, Cavalcanti MAQ (2016) Phaeosphaeria nodulispora, a new endophytic coelomycete isolated from tropical palm (Cocos nucifera) in Brazil. Nova Hedwigia 103 (1-2): 185-192. https://doi.org/10.1127/nova_hedwigia/ 2016/0343

Pereira NV, Safford HD, Behling H (2012) Holocene vegetation and fire history of the Serra do Caparaó, SE Brazil. The Holocene 22 (11): 1243-1250. https://doi.org/10.1177/0959683612437864

Ronquist F, Huelsenbeck JP (2003) MrBayes 3: Bayesian phylogenetic inference under mixed models. Bioinformatics 19 (12): 1572-1574. https://doi.org/10.1093/bioinformatics/btg180

Tamura K, Dudley J, Nei M, Kumar S (2007) MEGA 4: molecular evolutionary genetics analysis (MEGA) software version 4.0. Molecular Biology and Evolution 24 (8): 1596-1599. https://doi.org/10. 1093/molbev/msm092

Tedersoo L, Sánchez-Ramírez S, Kõljalg U, Bahram M, Döring M, Schigel D, May T, Ryberg M, Abarenkov K (2018) High-level classification of the Fungi and a tool for evolutionary ecological analyses. Fungal Diversity 90: 135-159. https://doi.org/10.1007/s13225018-0401-0

Wagner L, Stielow B, Hoffmann K, Petkovits T, Papp T, Vágvölgyi C, de Hoog GS, Verkley G, Voigt K (2013) A comprehensive molecular phylogeny of the Mortierellales (Mortierellomycotina) based on nuclear ribosomal DNA. Persoonia: Molecular Phylogeny and Evolution of Fungi 30: 77-93. https://doi.org/10.3767/00315 8513 X666268

White TJ, Bruns T, Lee SJWT, Taylor J (1990) Amplification and direct sequencing of fungal ribosomal RNA genes for phylogenetics. PCR protocols: a guide to methods and applications 18 (1): 315-322. https://doi.org/10.1016/B978-0-12-372180-8.50042-1 